\title{
A RARE AND CLINICALLY IMPORTANT BLOOD GROUP- BOMBAY BLOOD GROUP
}

\author{
CHOWDHURY F.S ${ }^{1}$, SIDDIQUI M.A.E ${ }^{2}$, RAHMAN KGM ${ }^{3}$,NASREEN $Z^{4}$, BEGUM H.A ${ }^{5}$, BEGUM H A ${ }^{6}$
}

\section{Introduction:}

Bombay blood group is the rarest blood group in the world. It is a blood group which shows absence of A,B,H antigens on red cells and presence of anti- A, anti-B and potent wide thermal range anti-H antibodies in serum reacting with all $\mathrm{O}$ blood group ${ }^{1}$.

Dr. Y.M. Bhende first discovered Bombay blood group in 1952 at Bombay in India now known as Mumbai. This is the reason why this blood group got the name Bombay blood group ${ }^{2}$.

\section{Prevalence}

At present about $0.0004 \%$ of the general human population have Bombay blood group, though in some places such as Mumbai local populations can have occurrences as much as .01\% of inhabitants ${ }^{3}$. People with this blood group are found in Maharashtra and some places of Karnataka which lies at the border of Maharashtra. In a recent study an incidence of 1 in 33 among Kutia Kondh tribe, 1 in 127 in Kondh tribe and 1 in 1244 among the tribal populations of Orissa is found. This is the highest incidence of Bombay blood group so far reported from India.4. The incidence of this phenotype as 1 in 13,000 individuals in Mumbai ${ }^{5}$. An incidence of 1 in 7600 after screening a large number of samples in Mumbai. ${ }^{6}$ In Maharashtra, reported the incidence of the Bombay phenotype as 1 in $4500^{7}$. Incidence is 1 in 18,404 amongst Indians settled in South Africa ${ }^{8}$. Of the 179 cases 112 (62.6\%) cases belonged to the state of Maharashtra. A slightly higher frequency of the Bombay phenotype was also found in the neighboring state of Karnataka (14 cases), Andhra Pradesh (8 cases), Goa (6 cases), Gujarat (5 cases), Uttar Pradesh (5 cases), and so on in the decreasing order ${ }^{8}$. The incidence of the Bombay phenotype is high in those states of India where consanguineous marriages are more prevalent, i.e.,
Andhra Pradesh, Tamil Nadu, Karnataka, Maharashtra, Gujarat, etc. than in the other states. Three cases of a rare blood group, Bombay (Oh) phenotype, in the Bhuyan tribe of Sundargarh district in North-Western Orissa were detected, Individuals with the Bombay blood group were also detected in Japan (Okubo 1980;Kaneko et al. 1997), Malaysia (Lopez, 1972),Thailand (Sringarm et al.1977) and Sri Lanka (De Zoysa 1985) ${ }^{9}$. H-deficient Bombay phenotype is rare, since it occurs in about 1 in 10,000 individuals in India and 1 per 1,000,000 individuals in Europe ${ }^{10}$. More recently, a large series (42 Hdeficients) of H-deficient individuals ( 1:1000) were found in a small French island $800 \mathrm{~km}$ east of Madagascar in the Indian Ocean, called Reunion Island $^{11}$. This indicates that the Bombay phenotype is mostly confined to South-East Asian countries.

People with bombay blood group in Bangladesh: No specific statistics of people with Bombay blood group in Bangladesh is available. The first person with Bombay blood group was identified in Bangladesh in Narayangonj. Till now four people of Bombay blood group found in Bangladesh. Among them three are sisters of same family ${ }^{12}$.So the transfusion centers should have the means and the thought to test for Bombay group.

\section{Genetics}

99.9\% of all individuals have an $\mathrm{HH}$ or Hh genotype. Individuals with the Bombay group have inherited two recessive alleles of the $\mathrm{H}$ gene (their genotype is " $\mathrm{hh}$ ") and so do not express $\mathrm{H}$ antigen ${ }^{13}$. A antigen and $\mathrm{B}$ antigen are made from $\mathrm{H}$ antigen. As a result, people with Bombay blood group cannot make A antigen or B antigen on their red blood cells. Because both parents must carry this recessive allele to transmit this blood type to their children, the condition mainly

1. Assistant Professor, Transfusion Medicine, National institute of Kidney Diseases and Urology.

2. Consultant, Cardiology, NITOR, Dhaka

3. Associate Professor, Forensic Medicine, Dhaka Medical College

4. Medical Officer, Transfusion Medicine, Dhaka Medical College

5. Professor, Transfusion Medicine, Dhaka Medical College

6. Associate Professor, Transfusion Medicine, Dhaka Medical College

Bangladesh J Medicine 2011; 22 : 21-23 


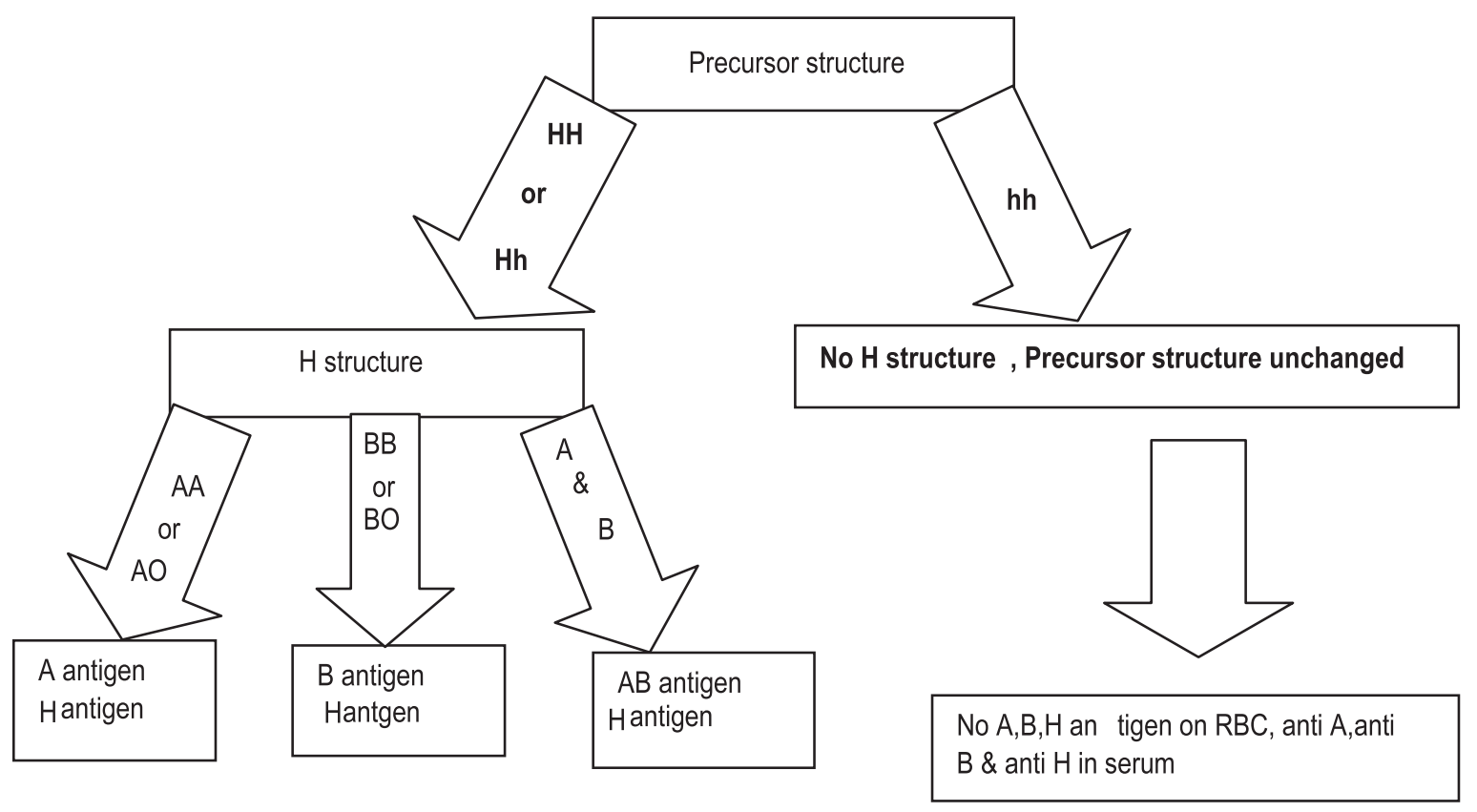

Fig.-1: Interaction of the Hh and $A B O$ gene.

occurs in small closed-off communities where there is a good chance of both parents of a child either being of Bombay type, or being heterozygous for the " $h$ " gene allele and so carrying the Bombay characteristic as recessive. Although $\mathrm{H}$ structure is responsible for formation of $\mathrm{A}$ and $\mathrm{B}$ antigen, there is separate gene for formation of $A$ and $B$ enzymes. So It is then no longer matters whether the A or B enzymes are present or not, no A or B antigen can be produced since the precursor antigen $\mathrm{H}$ is not present. When Bombay blood group was first encountered, it was found not to contain antigens $\mathrm{A}$ or B and so was thought to be of group O. But experience showed that Bombay group patients could not even safely receive normal O-group blood, and this proved to be because they lacked the $\mathrm{H}$ antigen and have potent wide thermal range anti $\mathrm{H}$.

\section{Detection}

It is very difficult to detect Bombay group people when usual blood group test is conducted. The usual tests for ABO blood group system would show them as group $O$. There is a serum grouping called reverse grouping for accurate test of a person's ABO group. If this test is conducted then we can detect the presence of $\mathrm{H}$ antibody, which indicate Bombay blood group. This test is conducted with the help of a reagent called $\mathrm{H}-$ Lectin which has anti-H like activity. Thus it is used to determine the presence or absence of the $\mathrm{H}$ antigen on the surface of RBCs. The Bombay phenotype detected was further confirmed by certain specialized tests like absorption-elution studies, titration of naturally occurring antibodies at different temperatures, hemagglutination-inhibition study on anti-H by $\mathrm{O}$ saliva secretor, and secretor-status of the person ${ }^{14,15}$.

\begin{tabular}{lcccccccc}
\hline \multicolumn{2}{c}{ Cell grouping } & \multicolumn{3}{c}{ Serum } & grouping & \multicolumn{3}{c}{ Interpretation } \\
Anti & A & Anti & B & Anti & AB & A cells & B cells & O cells \\
\hline+ & - & + & - & + & - & A \\
- & + & + & + & - & - & B \\
+ & + & + & - & - & - & AB \\
- & - & - & + & + & - & O \\
- & - & - & + & + & & Bombay \\
& - & & & & & & blood \\
& & & & & & & & group \\
\hline
\end{tabular}

Diagram as shown in above diagram, cell grouping is carried out using anti A, Anti B andante AB commercially available sera. Serum grouping is carried out using A cells, B cells and $\mathrm{O}$ cells

\section{General Characteristics of Bombay Blood Group: 13}

1. Absence of $\mathrm{H}, \mathrm{A}$, and $\mathrm{B}$ antigens; NO agglutination with anti-A, anti-B, or anti-H lectin.

2. Presence of anti-A, anti-B, anti-AB and potent wide thermal range anti-H in the serum.

3. A, B, H non-secretor (no A, B, or H substances present in saliva)

4. Absence of $\mathrm{H}$ enzyme in serum and $\mathrm{H}$ antigen on red cells. 
5. Presence of A or B enzymes in serum and red cells.

6. A recessive mode of inheritance.

7. Red cells of the Bombay group are compatible only with the serum from another Bombay individual.

\section{Transfusion Compatibility}

Individuals with Bombay blood group can donate to all ABO blood group people and can only accept from Bombay blood group people. The Bombay anti-H is an IgM antibody that can bind complement and cause red cell lysis.Because the $\mathrm{H}$ antigen is common to all ABO blood group, Bombay blood is incompatible with all $\mathrm{ABO}$ donors ${ }^{16}$.

Given that this condition is very rare, any person with this blood group who needs an urgent blood transfusion will probably be unable to get it, as no blood bank would have any stock. Those anticipating the need for blood transfusion (e.g. in scheduled surgery) may bank blood for their own use (i.e. an autologous blood donation), but this option is not available in case of accidental injury ${ }^{17}$.

\section{End Note}

Bombay blood group is a rare blood group mainly found in the South East Asia including Bangladesh. People having this blood group are very small in number. It doesn't mean that these people are having any disease or it's the symptom of any disease. People with Bombay blood group should report to the nearest blood bank. They are advised not to give blood in donation programs because it is not necessary that these Bombay blood will be used within 45 days. Relatives can have Bombay blood group, so they should be screened for Bombay blood group. People having Bombay blood group should be listed. Since Bombay Blood Group is the rarest of the rare group, it is desirable to develop cryopreservation facilities for rare donor units. Every blood bank can easily maintain a rare blood type donor file from their regular voluntary donors.It is only possible to solve problems related to rare blood groups like Bombay blood group if each blood bank has a large number of committed regular voluntary donors.

\section{References:}

1. kWatkins WM, Morgan WT."Possible genetic pathway for the biosynthesis of blood group mucopolysaccharides. Vox Sang 1959:4:97-119.
2. Brozovic B, Brozovic M, Manual of Clinical Blood Transfusion, $1^{\text {st }}$ edt, Charchill Livingstone, USA, 1986, 1-19.

3. Bhende YM, Deshpande CK, Bhatia HM, Sanger R, Race RR, Morgan WT, et al. A new blood group character related to the ABO system. Lancet $1952 ; 1: 903-4$

4. Balgir RS. Detection of a Rare "Bombay (Oh) Phenotype" among the Kutia Kondh Primitive Tribe of Orissa, India. Int J Hum Genet 2005;5:193-8.

5. Bhatia HM, Sanghvi LD. Rare blood groups and consanguinity Bombay phenotype. Vox Sang $1962 ; 7: 245-8$

6. Bhatia HM, Sathe MS. Incidence of Bombay Oh phenotype and weaker variants of A and B antigens in Bombay (India). Vox Sang 1974;27:524-32s

7. Gorakshakar AC, Sathe MS, Shirsat SR, Bhatia HM. Genetic studies in Ratnagiri and Sindhudurg districts of Maharashtra: Incidence of ABO, Rho (D), In a antigens, G-6-PD deficiency and abnormal hemoglobins. J Indian Anthrop Soc 1987;22:38-46

8. Sathe M, Vasantha K, Mhaisalkar P, Gorakshakar A. Distribution of Bombay (Oh) Phenotypes in India. J Indian Anthrop Soc 1988;23:277-80.

9. Balgir RS,Orissa Identification of a rare blood group, "Bombay (Oh) phenotype," in Bhuyan tribe of Northwestern Orissa, India. Indian Journal of Human Genetics:2007:13:3:101-13

10. Oriol R, Candelier JJ, Mollicone R. Molecular genetics of H. Vox Sang 2000;78:105-8.

11. Le Pendu J, Gerard G, Vitrac D, Juszczak G, Liberge $\mathrm{G}$, Rouger $\mathrm{P}$, et al . H-deficient blood groups of Reunion Island, II: Differences between Indians (Bombay Phenotype) and White (Reunion phenotype). Am J Hum Genet 1983;35:484-96

12. Rahman M, Abdullah AZ, Hossain M, Haque KM, Hossain MM, Bangladesh Med Research Council Bulletine, 1990,Dec:16(20):75-85.

13. Denise M, Modern Blood Banking and Transfision Practices. $3^{\text {rd }}$ edt,Jaypee Brothers, New Delhi. P: 92,100-102.

14. Flynn JC Jr. Essentials of Immunohematology. WB Saunders Company: Philadelphia; 1998. p. 23-39.

15. Boorman EK, Dodd BE, Lincoln PJ. Blood Group Serology. $6^{\text {th }}$ ed. Churchill Livingstone: Edinburgh; 1988. p. 179-99.

16. AABB, Technical Manual, $15^{\text {th }}$ edt,p-304. 